\title{
HOW TO PULL TYPES OF DISCRETION OUT OF KELSEN'S PURE THEORY OF LAW
}

\begin{abstract}
The expression hat-trick (signifying the scoring of three consecutive goals by one player) is very common in sports. In this short paper, coining the legal use of the expression, I will try to pull (3) types of discretion out of Hans Kelsen's Pure Theory of Law. Kelsen mentions discretion only in passing. While organizing the loose references to the topic I will analyze whether it can be said that an actual Kelsenian concept of discretion exists. Here, the focus will be on three textual moments in which discretion relevantly appears in Kelsen's Pure Theory of Law. These three moments, I will argue, can be connected to three types of discretion.
\end{abstract}

Key words: Hans Kelsen, Pure Theory of Law, Discretion, Determinability, Norm Conflict, Legal Gap.

\section{INTRODUCTION}

The expression hat-trick (signifying the scoring of three consecutive goals by one player) is very common in sports. But why exactly this feat is to be called a hat-trick is far less known. It turns out that the famous use of the expression originated in a cricket game in 1879 , where, upon taking three consecutive wickets, the club would reward the bowler with a new hat, although some suspect it has even older roots: i.e. the magic trick of pulling three objects, usually white rabbits, out of a hat. ${ }^{1}$

In this short paper, coining the legal use of the expression (in its magic trick version), I will try to pull (3) types of discretion out of Hans Kelsen's Pure Theory of Law. ${ }^{2}$

* $\quad$ PhD Student in Public Law (University of Lisbon). Member of the LxLTG (Lisbon Legal Theory Group) and Researcher at the CIDPCC

e-mail: anaescher@campus.ul.pt

The content of this paper was presented at the Conference "O pensamento de Hans Kelsen: influências, contexto e actualidade" held in December 2018 at the University of Lisbon School of Law.

1 Cf. the entry 'hat-trick' at https://www.etymonline.com.

2 Pure Theory of Law is to be read literally (i.e. including only the first and second edition of the work and excluding Kelsens theory of norms, as well as the works of other members of his school). 
Kelsen mentions discretion only in passing. ${ }^{3}$ While organizing the loose references to the topic I will analyze whether it can be said that an actual Kelsenian concept of discretion exists. Here, the focus will be on three textual moments in which discretion relevantly appears in Kelsen's Pure Theory of Law. These three moments, I will argue, can be connected to three types of discretion. That's the whole trick.

Revealing the method beforehand, it will be done in the following manner: first I say a few words as to the textual development of the topic in Kelsen's earlier work; ${ }^{4}$ then, focusing on the second edition of his Pure Theory of Law, I will analyze how and when discretion appears, trying to isolate the three mentioned moments. I will then connect these moments with different kinds or types of discretion. Lastly, I will finish with a critical reading in which I assess the central question of whether it can be said that a Kelsenian concept of discretion exists.

\section{Textual Development}

Let me start with a few words regarding the development of the topic in Kelsen's overall work. I would divide this development into two sections. A first section comprising his Habilitationsschrift and his paper on Die Lehre von den drei Gewalten oder Funktionen des Staates. And a second section which, already clearly taking into account developments from his pupils Adolf Merkl and Alfred Verdross, ranges from his seminal paper on interpretation to definitively the first (and conceivably the second) edition of the Pure Theory of Law. In fact, the chapter on interpretation of the first edition corresponds almost 1:1 to the content of Kelsen's 1934 article on interpretation. The few novelties in the second edition could then be attributed to a third section (the skeptical Kelsen), although in this paper I'm not going to analyze any further works than the second edition. ${ }^{5}$

The division criteria (debatable, as always) are, on one hand, the explicit mention to the topic of discretion and on the other hand, the connection of the topic to the dynamic nature of the law-making process and, therefore, the development of the latter itself. ${ }^{6}$

3 Cf. Elsner, T., 2011, Das Ermessen im Lichte der Reinen Rechtslehre, Rechtsstrukturtheoretische Überlegungen zur Rechtsbindung und zur Letztentscheidungskompetenz des Rechtsanwenders, Berlin, Duncker \& Humblot, p. 111.

4 Ranging from the Habilitationsschrift to the second edition of the Pure Theory.

5 For a comparison with Paulson's 3 phases of interpretation (and legal theory) see Paulson, S. L., 1990, Kelsen on Legal Interpretation, Legal Studies, Vol. 10, No. 2, pp. 136-152.

6 Presenting similar lines of division: Elsner. When it becomes apparent that all the cornerstones (including the dynamic nature of the law-making process) were already 
The often ignored basis is Kelsen's Habilitationsschrift from 1911, where, although still in a somewhat static and constructivist setting, he lays down a great deal of the ideas which characterize his view on the matters of interpretation, discretion and even hierarchical structure of the legal system. ${ }^{7}$ Here (free) discretion appears defined as absence of concrete legal determination: ${ }^{8}$

"Sowohl die Bedingungen, unter denen der Staat handeln will, als auch die Art und Weise seines Handelns selbst, sind im Rechtssatze niemals allseitig determiniert; vielmehr ist [...] dem zur Handlung verpflichteten Staatsorgane stets ein mehr oder weniger weiter Spielraum gegeben [...]."9

The demand for indeterminacy results from the very nature of execution of foreign will, as Kelsen illustrates with his example of the order of laying a book on a table. ${ }^{10}$ While the gesture of the hand, the exact spot on the table and the position of the book are still describable (maybe even the hand that should be used), an exhaustive description of all the muscle movements is as impossible as it is unpredictable. ${ }^{11}$

In his next example, Kelsen explores the relation between the abstract concept and the concrete image. Take the concrete tree he says, which necessarily has infinitely more properties than our abstract concept of tree

laid down in the Hauptprobleme the whole divide as such becomes questionable. Cf. Elsner, T., 2011.

7 Constructivist because of the focus on the concept of will, static because discretion here is only the discretion of the executive and the judiciary, while discretion implied in the legislative activity, namely in the constitutional interpretation, is not yet recognized. On this see Paulson, S. L., 1990 and Paulson, S. L., 1996, Hans Kelsen's Earliest Legal Theory: Critical Constructivism, The Modern Law Review, Vol. 59, No. 6 (Nov.), pp. 797-812. That Kelsen lays down the basis for his concept of discretion in his Habilitationsschrift is recognized by Elsner, T., 2011, p. 113 ss.

8 The equivocal concept of "freies Ermessen", free discretion (as opposed to bound discretion) is a traditional concept stemming from the german administrative doctrine, which, although employed in his early writings, was rightly criticized by Kelsen: discretion is always free and bound at the same time. See Kelsen, H., 1923, Hauptprobleme der Staatsrechtslehre entwickelt aus der Lehre vom Rechtssatze, 2. Aufl., Tübingen, Mohr Siebeck.

9 The conditions under which the state intends to act as well as the nature of its action itself are never completely determined by the norm formulation; rather the state organ which is compelled to act is always given, to a greater or lesser extent, a margin of leeway. Free translation of Kelsen, H., 1923, p. 504.

10 There is a slight doubt regarding the expression 'Unbestimmtheit'. Its transposal to the English language might mean i) indeterminacy (as chosen by Paulson); ii) uncertainty and; or iii) indefiniteness (as chosen by Max Knight). I consider indeterminacy to be the best translation.

11 Kelsen, H., 1923, p. 505. 
but nevertheless only is, in its totality, a tree precisely because it fulfills those properties demanded by the concept. In the same sense, the concrete act of the organ, in its manifoldness, is to be attributed to the state although its attribution rule does not present (cannot present) all elements of the action. ${ }^{12}$

Here, worried primarily about the concept of administrative discretion (although he explicitly seeks to equate the executive and judicial discretion) and tied to concepts like 'execution of foreign will' and 'order', Kelsen still seems to operate inside the static analysis of the legal system. ${ }^{13} \mathrm{Nev}$ ertheless, glimpses of the dynamic analysis are already visible in the very reference of the law creating process as necessarily implying Spielräume but specially in his already hierarchical description of the relation between the general, abstract concept and the concrete reality (his above tree example).

Another (one cannot help but call it) revolutionary move is Kelsens mention as early as in 1911 to the relation between discretion and norm structure. He identifies three possibilities: indeterminacy can be situated in the norm's antecedent (what he calls bedingter Tatbestand) (i), in the norm's consequence (what he calls Realisierung des bedingten Staatswillens) or in both (iii). The last scenario is compared to a blank form for the administrative organ.

In this small section of his Hauptprobleme, Kelsen also seeks to clarify the plurivocal nature of the concept in the literature of the time (and still of today as can be seen in the formal principle debate of the German law tradition) which described discretion, indistinguishably, as activity and as state, as a positive and negative feature of the legal system. ${ }^{14}$

Finally, Kelsen anticipates (although here renders it practically irrelevant) the distinction he will later pursue in his Pure Theory between direct and explicitly given discretion and indirect discretion conferred for instance by the employment of legal concepts whose content and scope are not or cannot be legally determined. He gives the curious (for their resemblance with the famous vehicle) example of 'rail' (but also the more expectable 'public interest').

If until now the dynamic elements were more on the discrete side, in Kelsen's 1924 paper Die Lehre von den Drei Gewalten, a clearly inter-

12 Kelsen, H., 1923, p. 505.

13 Kelsen, H., 1923, p. 504.

14 In formal principle theory, the question as to whether a situation of discretion exists (existence) is often not carefully separated from the question as to who has final discretion (competence). Highlighting the need for this distinction Klatt, M., Schmidt, J., 2012, Epistemic Discretion in Constitutional Law, International Journal of Constitutional Law, Vol. 10, No. 1, p. 104. 
mediate conception of the same idea of discretion emerges. Here, again $\grave{a}$ propos of the concept of free discretion, he states that the determination of the lower degree by the higher degree can never be complete, this is demanded by the very process of law creation:

"Diese notwendige Differenz zwischen höheren und niederen Stufe der Rechtskonkretisierung ist das sogenannte freie Ermessen." ${ }^{15}$

Kelsen highlights the nonsense of the use of the expression free discretion: it is clear that in so far as a state action is to be a state action it has to be legally bound and determined. Correspondingly the discretion is always free and bound at the same time. There is no contradiction. ${ }^{16}$ In the same sense, the difference between the discretion of the executive and the judiciary is just a quantitative one (it is merely contingent, dependent upon the conformation of the concrete normative system whether the executive or the judiciary is freer or more bound).

These initial Kelsenian elements of discretion were later relevantly pursued by two of Kelsens disciples: Alfred Verdross but specially Adolf Merkl (which should come with little surprise knowing he authored the Stufenbaulehre). ${ }^{17}$ In fact, the topic of discretion is a good example of the necessity of understanding the Pure Theory of Law (here not to be read in the strict way) as a truly collective work. ${ }^{18}$ Sure, Kelsen laid down the framework in his Hauptprobleme, but from here on certain topics were elaborated (sometimes in much more detail) by other authors of the school, only to be revisited and again developed by Kelsen himself (if he deemed them relevant enough), in a continuous and collective motion which often blurred the borders of authorship. ${ }^{19}$ Take the theory of discretion, the hierarchical structure of the legal system or even the views on

15 This needed difference between higher and lesser degree of the law concretization is the so called free discretion. Free translation of Kelsen, H., 1923/24, Die Lehre von den drei Gewalten oder Funktionen des Staates, Archiv für Rechts und Wirtschaftsphilosophie, Vol. 17, No. 3, p. 393.

16 Just a brief footnote to allude to a delightful Kelsenian footnote (no doubt related to his acquaintance with the Freudian circle). With regard to this issue, he makes the analogy with the human nature, namely that gender is not mutually exclusive but that an individual is always necessarily more or less female and more or less male. See Kelsen, H., 1923, footnote 1, p. 507.

17 This 'later' has to be read with a pinch of salt. While Kelsen wrote his Habilitationsschrift in 1911 (and what I termed his intermediate piece Die Lehre von den Drei Gewalten in 1923, Verdross's article is already from 1914 and Merkl's very relevant Doppelter Rechtsantlitz from 1918. Only Merkl's subsequent works, very in particular his Prolegema, stem from a later period (namely, 1931).

18 In this sense Elsner, T., 2011, p. 112.

19 For a better understanding of this inter-relation see Jabloner, C., 1998, Kelsen and his Circle: The Viennese Years, European Journal of International Law 9, pp. 368-385. 
legal interpretation, laid down in the Hauptprobleme but then developed exhaustively by Merkl. ${ }^{20}$ And while the Stufenbau was deemed absolutely central, rethought and absorbed by Kelsen in his subsequent works, a detailed theory of discretion and its limits, for instance, was not something Kelsen chose to make use of.

In this sense, a brief reference to Verdrosses early article Das Problem des freien Ermessens und die Freirechtsbewegung, written specifically on the topic of discretion and interesting mainly because it provides another instance of connection between discretion and legal gaps (something I analyze on section 3.3 of this paper). He mentions the completeness of the normative system in connection with his claim regarding the necessary existence of indeterminacy; he denies, although in a general manner, that there are situations in which the law alone is not able to provide a solution - what exists is an indeterminate solution due to alternative possible decisions in light of the law.

Merkl, on the other hand, does not develop the issue of discretion in a singular text but rather in a sheer array of texts. ${ }^{21}$ Although originally coming from an administrative viewpoint (his primary field) he develops discretion, and particularly the so called Ermessensfehlerlehre in great detail, something I cannot mirror here. ${ }^{22}$ I'll just leave you with the general pointers. In a nutshell, Merkl describes discretion as the emergence of Freiräume (leeways, spaces of discretion) in all processes of law creation, in which the law applying organ is not heteronomously bound but also acts autonomously. ${ }^{23}$

Having in mind Merkls pyramidal image of the norm-to-norm derivatory process, from the fact that in his Stufenbau the statute loses its centrality (being only the intermediate step in the process of legal concretization) follows what he calls the necessary interplay between the objective component of the legal cognition (Rechtsekenntnis) and the subjective elements entailed in the legal creation (Rechtserzeugung) and which, with the exception of the first and last degree, is bound to arise in all degrees of the law creation process. In this process the objective component is enriched from step to step with subjective elements in a growing heteronomous determination of the law. ${ }^{24}$ Discretion is precisely this subjective

20 For instance, Merkl analyzed the methods of interpretation in great detail. On this see Elsner, T., 2011, p. 118 onwards.

21 For an exhaustive list see Elsner, T., 2011, p. 118 onwards.

22 For an excellent account of Merkl's role in matters of discretion see Elsner, T., 2011, p. 118 onwards.

23 Cf. Elsner, T., 2011, p. 124.

24 Cf. Elsner, T., 2011, p. 123. 
element stemming from the law applier. ${ }^{25}$ But it is, I believe, in his Verwaltungsrecht where Merkl best defines discretion: as the "phenomenon of legal unboundedness of the organ" or, in the same line as Kelsen, as "renouncement of further determination". 26 Or still, in his ultimate definition of discretion, where he explicitly (versus Kelsen where this rationale is also implied but never stated) connects discretion to the concept of choice. Discretion is thus:

“[...] selbst ist nichts als die Wahlmöglichkeit zwischen einer Mehrzahl vom objektiven Recht eröffneter Lösungsmöglichkeiten". ${ }^{27}$

Finally, in Kelsens 1943 paper Zur Theorie der Interpretation and in his $1^{\text {st }}$ and $2^{\text {nd }}$ Reine Rechtslehre, as anticipated and well known, he clearly absorbed Merkl's hierarchical structure of the legal system and now fully functions inside a dynamic process of law creation. He now recognizes discretion at all the degrees of the law creation process instead of only the administrative and judicial level. Another change is that the topic of discretion, although rarely literally addressed, appears now embedded in and dependent upon his considerations on interpretation and the dynamic aspect of law. ${ }^{28}$

Despite being inherently affected by all the problems generally pointed at Kelsen's 'theory' (if there is such a thing) of interpretation, with regard to this particular topic it is possible to discern a line of continuity (leading me to the question about a Kelsenian concept of discretion). ${ }^{29}$ Take for instance, the divide between intentional and non-intentional indeterminacy, the idea of indeterminacy implied in the individuation and concretization process of law creation and so on.

But this, I hope, will become visible in the next sections of this paper.

25 Cf. Merkl, A. J., Das doppelte Rechtsantlitz. Eine Betrachtung aus der Erkenntnistheorie des Rechts, in: Hans Klecatsky, H., Marcic, R., Schambeck, H. (Hrsg.), 1918, Die Wiener rechtstheoretische Schule. Schriften von Hans Kelsen, Adolf Merkl, Alfred Verdross, Bd. 1, Wien, p. 1097.

26 Free translation from the original "Erscheinung rechtlicher Ungebundenheit des Staatsorgans" and "Verzicht auf nähere Determination". Cf. Merkl, A. J., 1927, p. 140. First seen in Elsner, T., 2011, p. 124.

27 In itself nothing else than the possibility of choice between a plurality of objectively and legally opened possibilities of solution. Free translation of Merkl, A. J., 1927, Allgemeines Verwaltungsrecht, Wien, Springer, p. 151.

28 See in particular Kelsen, H., 2005, Pure Theory of Law, Translation from the Second German Edition by Max Knight, New Jersey, The Lawbook Exchange, p. 236 ss for the dynamic aspect of law and p. 348 ss for interpretation.

29 On the difficult topic of Kelsen's interpretation theory see Vaquero, A. N., 2014 and Paulson, S. L., 1990. 


\section{Types of Discretion}

With this theoretical and evolutionary underpinning in mind, now on a more text-based analysis and focusing primarily on the second edition of Kelsen's Pure Theory of Law, I will identify and organize the loose references to discretion, highlighting three relevant moments. ${ }^{30}$

3.1. [...] in the case in which the content of the individual norm to be created by the court is predetermined by a positive general legal norm, a certain amount of discretion must be reserved for the law creating function of the court. The positive general norm cannot predetermine all the facts which make up the peculiarities of the concrete case [...]. The general norm is always only a frame within which the individual norm is to be created. But this frame can be narrower or wider. ${ }^{31}$

This determination can never be complete. The higher norm cannot bind in every direction [...]. There must always be more or less room for discretion so that the higher norm in relation to the lower one can only have the character of a frame to be filled by this act. ${ }^{32}$

These are the most straightforward mentions to discretion. Discretion appears here as a frame of gradual concretization and fits perfectly the historical development of the idea by Kelsen and his followers: as connected to necessary indeterminacy and to the absence of normative concretization.

3.2. Finally, the indefiniteness of the legal act that is to be performed may also be the result of the fact that two norms which both claim validity $[. .$.$] partly or wholly contradict each other. { }^{33}$

Then the following possibilities for the solution of the conflict exist: [...] the two norms can be understood to be subject to a choice by the law-applying organ, e.g., the judge $[\ldots] .^{34}$

In this excerpt discretion is not literally addressed but emerges as an answer to a situation of a norm conflict. The reading of these mentions as a

30 The basis is the original Kelsen, H., 1960, Reine Rechtslehre. Mit einem Anhang: Das Problem der Gerechtigkeit, 2. Aufl., Wien, and its translation by Max Knight, Kelsen, H., 2005.

31 Kelsen, H., 2005, p. 245.

32 Kelsen, H., 2005, p. 349.

33 Kelsen, H., 2005, p. 350.

34 Kelsen, H., 2005, p. 207. 
moment of discretion is defeasible since, in the absence of a conflict solving norm, the situation of conflicting norms at the same degree (general, general, individual, individual) necessarily poses a space of choice for the law applying organ - as Kelsen states in the second quote. This also shows how, although not expressly recognized, Kelsen seems to have employed Merkl's concept of discretion as choice.

3.3. [...] and that it is desirable, therefore, to authorize the court [...] to create an individual norm, whose content is not determined by a statute [...]. If he (the legislator) were to formulate this authorization in a theoretically correct fashion, that is, without fiction, he would have to say: "If the application of the valid legal order is unsatisfactory according to the moral-political opinion of the court in the present case then the court may decide the case according to its own discretion." But such a formulation would allow far too great authority to the court. The judge would be authorized to decide according to his own discretion [...]. ${ }^{35}$

In this last moment discretion appears as possible but refused answer to a situation of a legal gap. First of all, this reference poses interpretative and translational issues when compared to the excerpt in 3.1. There it seems translators and literature have unanimously interpreted discretion in its usual sense. Here on the other hand, the on first sight bewildering connection of discretion to legal gaps lead some translators to an alternative reading: they disregarded the use of the expression, considering it was not used in a legal and technical sense, thus substituting the original 'Ermessen', 'discretion' with the expression 'free assessment' or 'own will. ${ }^{36}$

My interpretative proposal here is to try to reconcile the excerpt of 3.1. and 3.3., assuming both relate to the idea of discretion in a legal and technical sense. This can be done by connecting the discretion with the idea of completeness of the legal systems, something already hinted by Verdross. ${ }^{37}$ Here the topic of discretion would be linked to the principle of prohibition (in Alchourrón and Bulygin's $[A \& B s]$ sense of 'everything that is not forbidden is permitted' or of 'everything is either forbidden or permitted'), obtaining (the first) two types of discretion: ${ }^{38}$

35 Kelsen, H., 2005, p. 248.

36 This happens, for instance with the Portuguese translation of the Pure Theory by Baptista Machado. See Kelsen, H., 2008, Teoria Pura do Direito, tradução de Baptista Machado, 7a edição, Almedina, Coimbra.

37 Cf. Elsner, T., 2011, p. 118.

38 Cf. Alchourrón, C. E., Bulygin, E., 1971, Normative Systems, Wien Springer, p. 169 ss. and Bulygin, E., 2010, Sobre la Equivalencia Pragmática entre Permiso y No Prohibición, DOXA, Cuadernos de Filosofía del Derecho, 33, pp. 283-296. 
(i) Discretion linked to normative determinability: corresponds to the early sense of discretion discussed so far, this would be an internal or intrasystemic discretion, necessarily existent in the sense of a narrower or wider frame of possibilities given by the general norm (see quote 3.1.).

(ii) Discretion linked to the completeness of normative systems (NS): this would be an external or extra systemic discretion, logically dependent upon the finding that the NS is incomplete, something that is refused by the pure theory. If the principle of prohibition holds inside NS $\mathrm{n}$ then everything is normatively regulated and there is no completeness discretion; if the said principle does not hold in NS $\mathrm{n}$ then completeness discretion exists (as in the example of the classical theories regarding legal gaps).

Just a brief note to recall that this type of discretion (and its refusal) expectedly shares all the controversial theoretical assumptions of Kelsen's construal of the completeness of NS, namely:

a. That the principle of prohibition implies the non-existence of legal gaps, i.e. the completeness of NS (against this A\&B with the finding that the principle of prohibition in the sense of a strong permission is merely contingent and in the sense of a weak permission is trivial) and;

b. That the non-existence of a normatively determined obligation for action $\mathrm{p}$ implies that the judge should reject the claim (against this $\mathrm{A} \& \mathrm{~B}$ with the finding that the defendant being 'not obliged' only means that the judge shall not condemn. And 'shall not condemn' has to be distinguished as a norm proposition while 'forbidden to condemn' is a norm. This means that in this situation we only have the absence of an obligation). ${ }^{39}$

This is all very well, the more careful reader might reply, but if Kelsen refuses the existence of completeness discretion it still seems unclear what he is talking about in 3.3., therefore the utility of this classificatory and interpretative exercise seems put into question.

Here I think, two situations have to be distinguished. One is the theoretically coherent answer of the Pure Theory, legal gaps do not exist, they are a fiction. This, in fact, constitutes the exceptional case of no discretion, for Kelsen, the judge has only one choice, to reject the claim.

The other is its counterpoint: classical literature or even the legislator (as in Kelsen's example of the Swiss civil code), can and often do

39 For all this, see Cf. Alchourrón, C. E., Bulygin, E., 1971; Bulygin, E., 2010. 
assume this type of fiction. This then, and here we already intuit the skeptical Kelsen, is the case of maximum (but note determinability) discretion where the judge is authorized to create an individual norm without any frame. ${ }^{40}$

The paradox is the following: for Kelsen, conceiving the existence of legal gaps (completeness discretion) implies necessarily a situation of determinability discretion: here, a situation that, in theory, was not indeterminate (note that the situation of an alleged no answer in NS $n$ has an answer - to reject the claim), in practice becomes the most indeterminate of all.

Thus, what I called completeness discretion, although denied by Kelsen, ends up being relevant for a better understanding of his concept of discretion and of legal gaps.

Lastly and with little surprise, quote 3.2. could then be read as alluding to a third type of discretion: Discretion linked to Consistency of NS (iii).

All in all, and this would be the hat-trick, the three highlighted textual moments can be connected to three types of discretion which flow from and have to be understood in accordance with the theoretical foundations of the pure theory: derivation, principle of prohibition and interpretation:

(i) Discretion appears as a frame of gradual concretization - Determinability discretion;

(ii) Discretion appears as possible but refused answer to a situation of a legal gap-Completeness discretion;

(iii) Discretion appears as an answer to a situation of a norm conflict - Consistency discretion.

I mentioned that, in the pure theory of law, Kelsen seemed to have employed the concept of choice in his descriptions of discretion. Let us work with the proposed types of discretion and connect them to the implied choices, naturally, as described by Kelsen himself.

Determinability discretion, generally to be characterized as unlimited choice of alternatives inside the frame, is divided by Kelsen into intentional/non-intentional indeterminacy. While he does not specify much in regard to intentional indeterminacy (although he gives examples, like a law that predicts that, in case of an epidemic outbreak, adequate measures ought to be taken, while the particular choice of measures is up to the administrative authority) he does list some (three, to be exact) situations of non-intentional indeterminacy. ${ }^{41}$ The first scenario is the use of ambig-

40 Cf. Kelsen, H., 2005, p. 245 ss.

41 Kelsen, H., 2005, p. 350. 
uous linguistic expressions in norm formulations (here different meanings of the wording are available, the choice is tendentially unlimited, there are no legal meta-criteria or interpretation methods exist that could select one correct meaning). The second scenario is the believed divergence between the wording of the norm and the legislator's intention (this divergence might be partial or total, it is partial when the legislators intention conforms at least with one of the meaning allowed by the wording, the choice is tendentially binary). The last scenario is indeterminacy resulting from the total or partial conflict of two norms (here one of the conflicting norms might be chosen or it may be assumed that the norms annul each other, the choice is tendentially ternary):

In all these cases of [...] indefiniteness at the lower level, several possibilities are open to the application of law. The legal act applying a legal norm may be performed in such a way that it conforms (a) with the one or the other of the different meanings of the legal norm, (b) with the will of the norm creating authority that is to be determined somehow, (c) with the expression which the norm-creating authority has chosen, (d) with the one or the other of the contradictory norms; or (e) the concrete case to which the two contradictory norms refer may be decided under the assumption that the two contradictory norms annul each other. In all these cases, the law to be applied constitutes only a frame within which several applications are possible, whereby every act is legal that stays within the frame. ${ }^{42}$

Note that here the situation of a norm conflict (what I called consistency discretion) appears explicitly mentioned as a case of non-intentional determinability discretion. In the next section, I'll say a few words regarding the coherence of this description. ${ }^{43}$

Finally, in regard to the legal gap situation, and this we already saw above, Kelsen lists two situations, the authorization for a frameless norm creation and the answer of the normative system as a whole ('principle of prohibition'):

This means that the court is authorized to create in this case an individual legal norm whose content is in no way predetermined by a general legal norm created by legislation or custom. [...] It is usually said that the court is authorized to function as a legislator. ${ }^{44}$

42 Kelsen, H., 2005, p. 351.

43 Kelsen's textual analysis on this topic is somewhat confusing. Three different moments, conflict between general norms, page 207, here he refers only a binary choice; conflict between two individual norms, page 208, again he refers only a binary choice and finally a conflict of norms without any specification of their degree, page 351, where the choice is ternary. See Kelsen, H., 2005.

44 Kelsen, H., 2005, p. 244. 
It follows [...] that a positive legal order can always be applied by a court to a concrete case, even when the legal order does not contain, according to the court's view, a general norm positively regulating the behavior of the defendant or the accused (...). For in this case his behavior is regulated negatively, that is, legally not prohibited, and in this sense permitted. ${ }^{45}$

While in the first case the degree of choice is at its maximum (unlimited choice without frame) in the second case there is no choice at all, the action is dismissed:

[...] this frame can be narrower or wider. It is the widest when a positive general norm contains only the authorization for the creation of the individual legal norm, without predetermining its content. ${ }^{46}$

The lack of a general legal norm [...] results in the dismissal of the plaintiff's action or the acquittal of the accused [...]. ${ }^{47}$

\section{Kelsenian Concept of Discretion}

We can now pinpoint the general outline of the topic in the Pure Theory. But the opening question remains unanswered: can it be said that an underlaying and coherent Kelsenian concept of discretion exists?

It does seem that only first type of discretion (determinability discretion) fits the possible and earlier concept of discretion as absence of concrete legal determination. ${ }^{48}$ My replying claim here is that upon closer analysis all three types (i.e. all situations of discretion Kelsen mentions) can be understood as a matter of determination. This is so, I believe, because Kelsen's leading idea was outcome discretion (versus source discretion). ${ }^{49}$ So, in all his descriptions we will find a normative situation with an indeterminate solution. Ultimately, all boils down to a situation of indeterminacy (i.e. determinability discretion).

While he listed several sources from which this indeterminate outcome might arrive (which led me to the above mentioned three types), he did so not with a classificatory or exhaustive intent but in a merely descriptive and exemplificatory manner.

45 Kelsen, H., 2005, pp. 245, 246.

46 Kelsen, H., 2005, p. 245.

47 Kelsen, H., 2005, p. 247.

48 See supra note 8 and accompanying text.

49 This idea of source discretion and outcome discretion can also be found in Chiassoni, P., 2019, Interpretation without Truth, A Realistic Enquiry, Switzerland, Springer, p. 221 ss. 
The situations he listed are the following (already visible in his account of choices):

i. Indeterminacy of outcome due to a norm conflict;

ii. Indeterminacy of outcome due to a norm that, creating the fiction of a legal gap, authorizes the judge to create a frameless norm;

iii. Indeterminacy of outcome due to explicit normative prediction, the epidemy example;

iv. Indeterminacy of outcome due to conflict of interpretative methods;

v. Indeterminacy of outcome due to the use of ambiguous language.

This possible Kelsenian concept of discretion emphases therefore only the necessary indeterminacy implied in the normative outcome. The detailed identification of the sources of that indeterminacy are of lesser significance (although presupposed here and there) as is the consequence of a situation of discretion (although the concept of choice is presupposed and exemplified here and there).

It is precisely this reading of discretion (as indeterminacy of outcome) that allows for the joint mention of situations as a norm conflict, a linguistic uncertainty or a legal gap.

Additionally, and with this I will finish, this possible Kelsenian concept of discretion seems somewhat called into question with his interpretation 'theory'. ${ }^{50}$ For one, it is highly dependent upon the presupposed but never outlined criteria for assessing the frame itself and at the end seems to dissolve completely when the third Kelsen (more and more convinced by the distinction between acts of cognition and acts of will) foresees the creation of a norm completely outside the frame. This, then, would be total discretion:

By way of authentic interpretation, that is, the interpretation of a norm by the legal organ applying it, not only can one of the possibilities be realised that are brought out by the cognitive interpretation of the norm to be applied, but also a norm can be created that lies completely outside the frame represented by the norm to be applied. ${ }^{51}$

50 A brief note regarding another relevant topic: the question about the type indeterminability thesis Kelsen adopts - whether for him the whole NS is indeterminate. While he seems indeed to tend towards this thesis by, as we saw, alluding to the necessarily implied indeterminacy in the law creating process, he mentions (at least) one situation which would be determined not giving rise to any discretion - legal gap situation where the judge has to reject the claim. For a summary of the debate between Bulyigin, Lifante and Ruiz Manero see Vaquero, A. N., 2014, Kelsen en la Encrucijada: Ciencia Jurídica e Interpretatión del Derecho, Ius et Praxis, Año 20, No. 2, p. 426.

51 Kelsen, H., 2005, p. 354. 


\section{BIBLIOGRAPHY}

1. Alchourrón, C. E., Bulygin, E., 1971, Normative Systems, Wien, Springer.

2. Bulygin, E., 2010, Sobre la Equivalencia Pragmática entre Permiso y No Prohibición, DOXA, Cuadernos de Filosofía del Derecho, 33.

3. Chiassoni, P., 2019, Interpretation without Truth, A Realistic Enquiry, Switzerland, Springer.

4. Elsner, T., 2011, Das Ermessen im Lichte der Reinen Rechtslehre, Rechtsstrukturtheoretische Überlegungen zur Rechtsbindung und zur Letztentscheidungskompetenz des Rechtsanwenders, Berlin Duncker \& Humblot.

5. Jabloner, C., 1998, Kelsen and his Circle: The Viennese Years, European Journal of International Law, 9.

6. Kelsen, H., 1923, Hauptprobleme der Staatsrechtslehre entwickelt aus der Lehre vom Rechtssatze, 2. Aufl., Tübingen, Mohr Siebeck.

7. Kelsen, H., 1923/24, Die Lehre von den drei Gewalten oder Funktionen des Staates, Archiv für Rechts und Wirtschaftsphilosophie, Vol. 17, No. 3.

8. Kelsen, H., 1934, Zur Theorie der Interpretation, Internationale Zeitschrift für Theorie des Rechts, Bd. 8.

9. Kelsen, H., 1934, Reine Rechtslehre. Einleitung in die rechtswissenschaftliche Problematik, 1. Aufl., Leipzig und Wien.

10. Kelsen, H., 1960, Reine Rechtslehre. Mit einem Anhang: Das Problem der Gerechtigkeit, 2. Aufl., Wien.

11. Kelsen, H., 1990, On Theory of Interpretation, translated by Bonnie Litschewski Paulson and Stanley L. Paulson, Legal Studies, Vol. 10, No. 2.

12. Kelsen, H., 1992, Introduction to the Problems of Legal Theory, A Translation of the First Edition of the Reine Rechtslehre by Bonnie Litschewski Paulson and Stanley L. Paulson, Oxford, Clerendon Press.

13. Kelsen, H., 2005, Pure Theory of Law, Translation from the Second German Edition by Max Knight, The Lawbook Exchange, New Jersey.

14. Kelsen, H., 2008, Teoria Pura do Direito, tradução de Baptista Machado, 7a edição, Almedina, Coimbra.

15. Klatt, M., Schmidt, J., 2012, Epistemic Discretion in Constitutional Law, International Journal of Constitutional Law, Vol. 10, No. 1.

16. Merkl, A. J., Das doppelte Rechtsantlitz. Eine Betrachtung aus der Erkenntnistheorie des Rechts, in: Klecatsky, H., Marcic, R., Schambeck, H. (Hrsg.), 1918, Die Wiener rechtstheoretische Schule. Schriften von Hans Kelsen, Adolf Merkl, Alfred Verdross, Bd. 1, Wien.

17. Merkl, A. J., 1927, Allgemeines Verwaltungsrecht, Wien, Springer.

18. Merkl, A. J., Prolegomena einer Theorie des rechtlichen Stufenbaues, in: Klecatsky, H., Marcic, R., Schambeck, H. (Hrsg.), 1931, Die Wiener rechtstheoretische Schule. Schriften von Hans Kelsen, Adolf Merkl, Alfred Verdross, Bd. 2, Wien, 1311-1361.

19. Paulson, S. L., 1990, Kelsen on Legal Interpretation, Legal Studies, Vol. 10, No. 2.

20. Paulson, S. L., 1996, Hans Kelsen's Earliest Legal Theory: Critical Constructivism, The Modern Law Review, Vol. 59, No. 6 (Nov.). 
21. Paulson, S. L., 2008, Formalism, 'Free Law', and the 'Cognition' Quandary: Hans Kelsen's Approaches to Legal Interpretation, The University of Queensland Law Journal, Vol. 72(2), 7-39.

22. Vaquero, A. N., 2014, Kelsen en la Encrucijada: Ciencia Jurídica e Interpretatión del Derecho, Ius et Praxis, Año 20, No. 2.

23. Verdross, A., 1914, Das Problem des freien Ermessens und die Freirechtsbewegung, Österreichische Zeitschrift für öffentliches Recht, 1.

\section{O MESTU DISKRECIONE OCENE U KELZENOVOJ ČISTOJ TEORIJI PRAVA}

Ana Ešer

\section{REZIME}

Imajući u vidu da Kelzen pominje diskrecionu ocenu samo usput, rad počinje pregledom tekstualnog razvoja diskrecione ocene kroz celokupan Kelzenov opus, kao i kroz opus njegovih učenika Alfreda Verdrosa i Adolfa Merkla. Usredsredivši se na drugo izdanje Kelzenove Čiste teorije prava, rad odgovara na pitanje da li kelzenovski koncept diskrecione ocene stvarno postoji. Naglasak se stavlja na tri tekstualna odlomka Kelzenove Čiste teorije prava u kojima se diskreciona ocena jasno pominje.

U prvom izdvojenom tekstualnom odlomku, diskreciona ocena se javlja kao okvir postepene konkretizacije i savršeno odgovara istorijskom razvoju Kelzenove ideje: dakle, u vezi sa nužnom neodređenošću i odsustvom normativne konkretizacije. U drugom tekstualnom odlomku diskreciona ocena se ne pominje doslovno, ali se javlja kao odgovor u slučaju sukoba normi. Ovo tumačenje je oborivo budući da ako ne postoji norma koja rešava ovaj sukob, konflikt normi istog nivoa (opšta, opšta, pojedinačna, pojedinačna) neminovno ostavlja mogućnost izbora organima primene zakona - kako to sam Kelzen navodi.

U trećem (poslednjem) tekstualnom odlomku, diskreciona ocena se pojavljuje kao moguć ali neprihvaćen odgovor na problem postojanja pravne praznine. $U$ radu se posebno ističe da referenca na ovaj odlomak predstavlja pitanje interpretacije i prevoda. Povezanost diskrecione ocene sa pravnom prazninom uputila je neke prevodioce na alternativno tumačenje: tvrdi se, naime, da taj odlomak teksta nije korišćen u formalnom smislu zamenjujući tako pravi 'Ermessen', 'diskrecionu ocenu' izrazom 'slobodna procena' ili 'slobodna volja'.

U radu se predlaže da se usaglase gledišta oba tekstualna odlomka u kojima se pominje diskreciona ocena (kao okvir postepene konkretizacije i kao moguć odgovor na problem pravne praznine) jer se pretpostavlja 
da se oba odnose na ideju diskrecione ocene u formalnom smislu. To se može izvesti povezivanjem diskrecione ocene sa idejom celovitosti pravnog sistema, nešto što je već nagovestio Verdros.

Povezivanje sva tri navedena tekstualna odlomka autorku dovode do zaključka o sledeće tri vrste diskrecione ocene: odrediva, celovita i konzistentna diskreciona ocena.

U traganju za odgovorom na pitanje da li postoji osnovani i koherentni kelzenovski koncept diskrecione ocene, u radu se navodi da se po svemu sudeći samo prvi tip diskrecione ocene (odrediva diskreciona ocena) uklapa u mogući i početni koncept diskrecione ocene kao odsustvo kompletne pravne odredivosti. Posle detaljne analize, autorka ističe da se sve tri vrste (to jest sve situacije diskrecione ocene koje Kelzen pominje) mogu shvatiti kao stvar rešavanja problema neodređenosti prava. Rad se završava tvrdnjom da je Kelzenova vodeća ideja bila ishodna diskreciona ocena, a ne izvorna diskreciona ocena. Ovaj mogući kelzenovski koncept ističe stoga samo nužnu neodređenost izraženu u normativnom ishodu. Autorka navodi da je detaljna identifikacija izvora te neodređenosti manjeg značaja (mada pretpostavljena tu i tamo) od posledica koje proizvode situacije sa diskrecionom ocenom (mada se tu i tamo koncept izbora pretpostavlja i navodi kao primer).

Ključne reči: Hans Kelzen, čista teorija prava, diskreciona ocena, odredivost, sukob norme, pravna praznina.

Article History:

Received: 25 October 2019

Accepted: 28 November 2019 